\title{
Ischemic colitis after weight-loss medication
}

\author{
Dan Comay $M D^{1}$, Jennifer Ramsay $M D^{2}, E$ Jan Irvine $M D^{3}$
}

D Comay, J Ramsay, EJ Irvine. Ischemic colitis after weightloss medication. Can J Gastroenterol 2003;17(12):719-721 .

BACKGROUND: Previous weight-loss medications have received cautious support due to their association with pulmonary hypertension and valvular heart disease. However, newer drugs are increasingly being recommended as potentially safer and more efficacious. We report a case of ischemic colitis possibly linked to the use of a weightloss drug, and review the literature to highlight an important latent consequence of these medications.

CASE REPORT: A 59-year-old obese woman presented to the emergency room with rectal bleeding and suprapubic abdominal pain. Her medical history was unremarkable for risk factors for bowel ischemia. An appetite suppressant, phentermine $15 \mathrm{mg}$ daily, had been prescribed, and had resulted in a $12 \mathrm{~kg}$ weight loss over 10 weeks. Colonoscopy and biopsies both demonstrated findings typical of mild ischemia at the splenic flexure.

DISCUSSION: Phentermine, an amphetamine-derived sympathomimetic, acts centrally to suppress appetite. While there are no published reports linking the use of phentermine as a single agent to ischemic colitis, phentermine alone has been associated with ischemic neurological events and, when used in combination with fenfluramine, has been implicated in a single case of acute ischemic colitis. Other sympathomimetics, such as cocaine, have been clearly linked with ischemic colitis.

CONCLUSIONS: This report describes a temporal association with the use of phentermine and the development of ischemic colitis. Heightened awareness and appropriate surveillance is warranted to determine whether the use of weight-loss drugs, such as phentermine, can lead to ischemic colitis.

\section{Une colite ischémique après la prise d'un médicament amaigrissant}

\begin{abstract}
HISTORIQUE : Des médicaments amaigrissants ont déjà reçu un accord prudent en raison de leur association avec une hypertension pulmonaire et une cardiopathie valvulaire. Cependant, de nouveaux médicaments sont de plus en plus recommandés en raison de leur potentiel d'innocuité et d'efficacité plus élevé. Nous déclarons un cas de colite ischémique pouvant être relié à la prise d'un médicament amaigrissant et procédons à une analyse bibliographique pour souligner une conséquence latente grave de ces types de médicament.
\end{abstract}

RAPPORT DE CAS : Une femme obèse de 59 ans s'est présentée à l'urgence en raison d'une hémorragie rectale et de douleurs abdominales suprapubiennes. Ses antécédents médicaux ne laissaient songer à aucun facteur de risque d'ischémie intestinale. Un coupe-faim, sous forme de $15 \mathrm{mg}$ par jour de phentermine, lui avait été prescrit et lui avait fait perdre $12 \mathrm{~kg}$ en dix semaines. La coloscopie et les biopsies ont permis de découvrir des constatations types d'une ischémie bénigne à l'angle splénique.

EXPOSÉ : Le phentermine, un sympathomimétique dérivé de l'amphétamine, agit centralement pour couper l'appétit. Bien qu'il n'existe aucun compte rendu publié reliant l'utilisation du seul p hentermine à la colite ischémique, le phentermine seul s'associe à des atteintes neurologiques ischémiques et, combiné à la fenfluramine, à un seul cas de colite ischémique aiguë. D'autres sympathomimétiques, tels que la cocaïne, sont clairement reliés à la colite ischémique.

CONCLUSIONS : Le présent compte rendu décrit une association temporelle entre l'utilisation de phentermine et l'apparition d'une colite ischémique. Une sensibilisation accrue et une surveillance convenable s'imposent pour déterminer si l'usage de coupe-faim comme le phentermine peut provoquer une colite ischémique.

Key Words: Ischemic colitis; Obesity; Weight-loss medications

Ischemic colitis is a common cause of lower gastrointestinal bleeding, accounting for 10\% to 19\% of hospital admissions for lower gastrointestinal bleeding $(1,2)$. Ischemic colitis is a consequence of inadequate mesenteric blood flow that fails to meet intestinal metabolic demands, and is frequently observed in the arterial watershed areas, such as the splenic flexure (3). Several additional risk factors have been implicated to contribute to the development of ischemic colitis and are shown in Table 1.

Phentermine, a commonly prescribed weight-loss drug, is currently approved for short term weight loss (4). It is an amphetamine derivative that stimulates norepinephrine release in the hypothalamus to suppress appetite centrally (5). Its use, in combination with fenfluramine, increased sharply following the publication of the fenfluramine-phentermine ("fen-phen") study, demonstrating its superiority to placebo for weight reduction (6). However, subsequent reports linking fenfluramine and dexfenfluramine to the development of pulmonary hypertension and cardiac valvular abnormalities led to a dramatic decline in their use, as well as that of phentermine $(7-10)$. Both fenfluramine and dexfenfluramine were subsequently withdrawn from the market (11).

We report a case of ischemic colitis following the use of a common weight-loss drug, phentermine, in a patient without other risk factors for large bowel ischemia, and review the literature to illustrate a potential important consequence of this medication.

\section{CASE PRESENTATION}

A 59-year-old woman presented to the emergency department at Hamilton Health Sciences (McMaster University, Hamilton, Ontario) with a history of passing bright red loose

Departments of ${ }^{1}$ Medicine (Gastroenterology) and ${ }^{2}$ Pathology, McMaster University, Hamilton, Ontario; ${ }^{3}$ Department of Medicine

(Gastroenterology), University of Toronto, Toronto, Ontario

Correspondence: Dr EJ Irvine, Division of Gastroenterology, St Michael's Hospital, Room 16-052 Cardinal Carter Wing, 30 Bond Street,

Toronto, Ontario M5B 1W8. Telephone 416-864-5060, fax 416-861-8378, e-mail irvinej@smh.toronto.on.ca

Received for publication June 25, 2003. Accepted September 17, 2003 


\section{TABLE 1}

\section{Selected risk factors for ischemic colitis}

Aortic or cardiac surgery $(23,24)$
Major cardiovascular episode (eg, cardiac failure, shock) $(25)$
Major vascular occlusion (eg, mesenteric venous thrombosis) $(26)$
Vasculitis (eg, systemic lupus erythematosus, polyarteritis nodosa) $(27,28)$
Hypercoagulable state (29)
Infection (eg, Escherichia coli O157:H7, cytomegalovirus) $(30,31)$
Prolonged physical exertion (eg, long-distance running) $(32)$
Drugs: estrogen (33), pseudoephedrine (15-17), methamphetamine (18-20),
cocaine (21,22), nonsteroidal anti-inflammatory drugs (34),
aloestron hydrochloride (35)

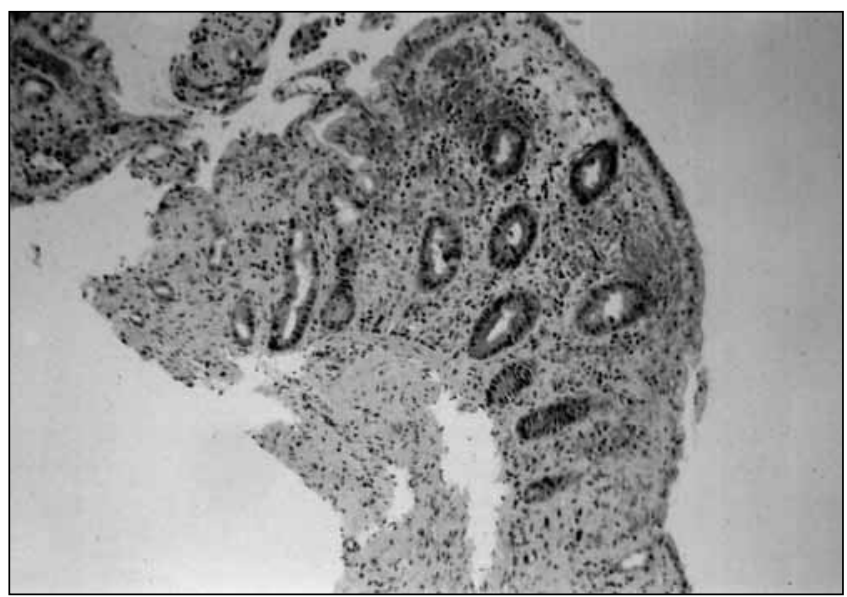

Figure 1) Acute ischemic colitis (biopsy magnification 100x). There is hemorrhage and a mixed inflammatory cell infiltrate in the lamina propria. The mucosa shows regenerative changes of increased basophilia and mucin depletion

stool that was preceded by several hours of severe, crampy, suprapubic abdominal pain. She had three bloody bowel movements that produced approximately $175 \mathrm{~mL}$ and a one-day history of nausea and bilious vomiting without blood or coffee-ground material. She denied having fevers or rigors and had noted an intentional weight loss of $12 \mathrm{~kg}$ (from $82 \mathrm{~kg}$ to $70 \mathrm{~kg}$ ) over 10 weeks, after starting the phentermine. She had also experienced two self-limited episodes of suprapubic abdominal pain with nonbloody diarrhea four weeks and eight weeks after starting the drug, but did not seek medical attention.

She had no prior history or symptoms suggestive of inflammatory bowel disease and no recent history of antibiotic use, well-water consumption or eating commercially prepared meals. She had recently travelled to Virginia and eaten in a communal dining hall, but no known contacts had fallen ill and her travelling companion had remained well.

Her medical history was significant for inflammatory osteoarthritis, asthma, gastroesophageal reflux disease, mild hypertension and paroxysmal supraventricular tachycardia. She had no symptoms of ischemic heart disease, and an extensive cardiac work-up, performed one year previously for tachycardia, had been normal. Her mother had left-sided ulcerative colitis.

Her medications included prednisone $5 \mathrm{mg}$ daily, verapamil $180 \mathrm{mg}$ twice daily, albuterol puffer as needed, budesonide two puffs twice daily, esomeprazole $40 \mathrm{mg}$ daily, acetominophen

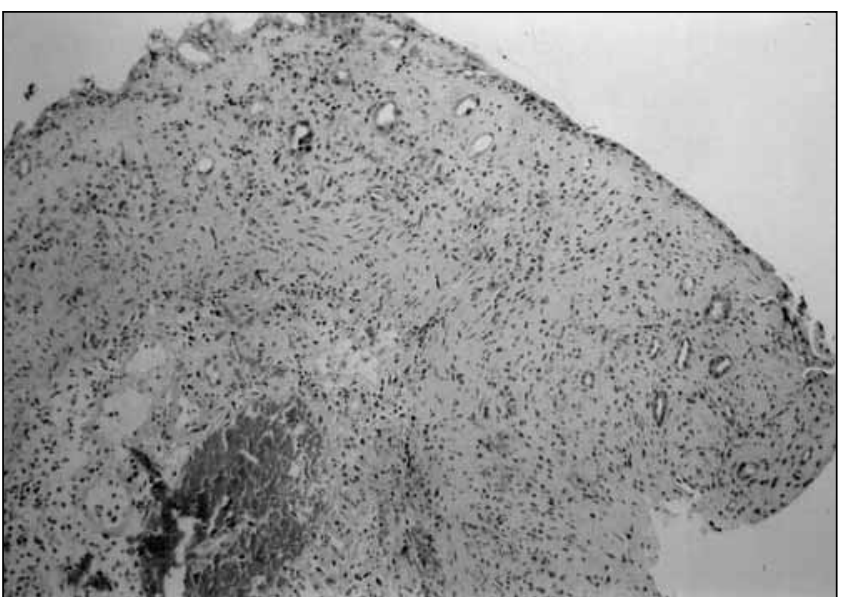

Figure 2) Remote ischemic injury (biopsy magnification 100x). There is marked fibrosis and loss of glandular mucosa (gland drop-out) in the lamina propria

with codeine as needed for arthralgia and phentermine resin (Ionamin, Celltech Pharmaceuticals, USA) one $15 \mathrm{mg}$ capsule taken daily before breakfast. She had previously taken estrogen replacement for postmenopausal symptoms but discontinued this medication on her physician's advice three months before her presentation.

She was a lifelong nonsmoker, rarely consumed alcohol and drank four to six cups of tea daily. She had a sedentary lifestyle with no high-endurance pursuits. She had a remote cholecystectomy and had an allergy to nonsteroidal anti-inflammatory drugs, which caused her to wheeze.

On arrival at the emergency department, her blood pressure was $144 / 80 \mathrm{mmHg}$, heart rate was 90 beats/min and regular, and there was no postural change in either. She was afebrile. Her cardiovascular and respiratory examinations were within normal limits. On examination of the abdomen, bowel sounds were present and she had mild left lower quadrant tenderness without rebound tenderness or guarding. A digital rectal examination revealed an empty rectal vault with bright red blood on the examining glove.

Blood chemistry panel and coagulation profiles were normal. Apart from a mildly elevated white blood cell count of $11.9 \times 109 / \mathrm{L}$, the complete blood count was normal. A selected panel of bloodwork to exclude vasculitis - including C-reactive protein, antinuclear antibodies, extractable nuclear antibodies, rheumatoid factor, and C3 and C4 levels - was normal. Screening for antineutrophilic cytoplasmic antibodies was not performed.

Stool examinations were performed to exclude the presence of pathogens and Clostridium difficile toxin. Abdominal $\mathrm{x}$-rays revealed multiple fluid-filled loops of bowel without distension, thumb-printing, air-fluid levels or free intraperitoneal air.

A colonoscopy, performed within $12 \mathrm{~h}$ of hospitalization, demonstrated $10 \mathrm{~cm}$ of edematous, ulcerated, hemorrhagic mucosa at the splenic flexure with normal flanking mucosa. Biopsies showed features of both acute ischemic colitis (Figure 1) and chronic ischemic morphological features, such as fibrosis (Figure 2).

The patient improved quickly with intravenous fluid administration and supportive care and was discharged home after five days of observation. She remains asymptomatic four months later and has not resumed her weight-loss medication. 


\section{DISCUSSION}

There are no published reports to date of phentermine use alone in association with ischemic colitis. There was, however, a single case report of a healthy 36-year-old woman who developed ischemic colitis while taking fenfluramine-phentermine (12). She had lost $14 \mathrm{~kg}$ while on a combination of fenfluramine $20 \mathrm{mg}$ and phentermine $30 \mathrm{mg}$ three times per day for three months. She had no risk factors for bowel ischemia, apart from remote birth-control pill use, rare nonsteroidal anti-inflammatory drug use and smoking five cigarettes per week.

Phentermine has also been described in association with ischemic neurological events in two patients (13). One patient had a seven-day hemisensory disturbance consistent with a transient ischemic attack, while the other patient had a right occipital infarct with multiple vascular abnormalities on cerebral angiogram.

\section{REFERENCES}

1. Comay D, Marshall JK. Resource utilization for acute lower gastrointestinal hemorrhage: The Ontario GI Bleed Study. Can J Gastroenterol 2002;16:677-82.

2. Newman JR, Cooper MA. Lower gastrointestinal bleeding and ischemic colitis. Can J Gastroenterol 2002;9:597-600.

3. MacDonald PH. Ischaemic colitis. Best Pract Res Clin Gastroenterol 2002;16:51-61.

4. Glazer G. Long-term pharmacotherapy of obesity 2000: A review of efficacy and safety. Arch Intern Med 2001;161:1814-24.

5. Halpern A, Mancini MC. Treatment of obesity: An update on antiobesity medications. Obes Rev 2003;4:25-42.

6. Weintraub M, Hasday JD, Mushlin AI, Lockwood DH. A doubleblind clinical trial in weight control: Use of fenfluramine and phentermine alone and in combination. Arch Intern Med 1984;144:1143-8.

7. Mark EJ, Patalas ED, Chang HT, et al. Fatal pulmonary hypertension associated with short-term use of fenfluramine and phentermine. N Engl J Med 1997;337:602-6.

8. Simonneau G, Fartoukh M, Sitbon O, et al. Primary pulmonary hypertension associated with the use of fenfluramine derivatives. Chest 1998;114:195S-9S.

9. Connolly HM, Crary JL, McGoon MD, et al. Valvular heart disease associated with fenfluramine-phentermine. N Engl J Med 1997;337:581-8.

10. Cannistra LB, Davis SM, Bauman AG. Valvular heart disease associated with dexfenfluramine. N Engl J Med 1997;337:636.

11. Cardiac valvulopathy associated with exposure to fenfluramine or dexfenfluramine: U.S. Department of Health and Human Services interim public health recommendations, November 1997. MMWR Morb Mortal Wkly Rep 1997;46:1061-6.

12. Schembre DB, Boynton KK. Appetite-suppressant drugs and primary pulmonary hypertension. N Engl J Med 1997;336:510-1.

13. Kokkinos J, Levine SR. Possible association of ischemic stroke with phentermine. Stroke 1993;24:310-3.

14. Texter EC Jr, Chou C-C, Merrill SL, et al. Direct effects of vasoactive agents on segmental resistance of the mesenteric and portal circulation: Studies with 1-epinephrine, levarterenol, angiotensin, vasopressin, acetylcholine, methacholine, histamine, and serotonin. J Lab Clin Med 1964;64:624-33.

15. Beyer KL, Bickel JT, Butt JH. Ischemic colitis associated with dextroamphetamine use. J Clin Gastroenterol 1991;13:198-201.

16. Dowd J, Bailey D, Moussa K, et al. Ischemic colitis associated with pseudoephedrine: Four cases. Am J Gastroenterol 1999;94:2430-4.

17. Lichtenstein GR, Yee NS. Ischemic colitis associated with decongestant use. Ann Intern Med 2000;132:682.
The putative mechanism by which phentermine may cause ischemic colitis is based on its pharmacological properties. Phentermine is a beta-phenethylamine derivative of amphetamine and stimulates norepinephrine release from nerve terminals, such as in the intestinal vasculature (5). The resulting adrenergic stimulation may lead to mesenteric vasoconstriction and tissue ischemia (14). Other sympathomimetic agents, such as cocaine, methamphetamine and pseudoephedrine have been well documented to cause ischemic colitis through similar mechanisms (15-22).

\section{CONCLUSION}

This case report describes a temporal association between the use of phentermine and the development of ischemic colitis. Heightened awareness and appropriate surveillance is warranted to determine whether the use of weight-loss drugs, such as phentermine, can lead to ischemic colitis.

18. Dirkx CA, Gerscovich EO. Sonographic findings in methamphetamine-induced ischemic colitis. J Clin Ultrasound 1998;26:479-82.

19. Johnson TD, Berenson MM. Methamphetamine-induced ischemic colitis. J Clin Gastroenterol 1991;13:687-9.

20. Herr RD, Caravati EM. Acute transient ischemic colitis after oral methamphetamine ingestion. Am J Emerg Med 1991;9:406-9.

21. Linder JD, Monkemuller KE, Raijman I, et al. Cocaine-associated ischemic colitis. South Med J 2000;93:909-13.

22. Niazi M, Kondru A, Levy J, Bloom AA. Spectrum of ischemic colitis in cocaine users. Dig Dis Sci 1997;42:1537-41.

23. Hagihara PF, Ernst CB, Griffen WO. Incidence of ischemic colitis following abdominal aortic reconstruction. Surg Gynecol Obstet 1979;149:571-3

24. Welling RE, Rath R, Albers JE, Glaser RS. Gastrointestinal complications after cardiac surgery. Arch Surg 1986;121:1178-80.

25. Simic O, Strathausen S, Hess W, Ostermeyer J. Incidence and prognosis of abdominal complications after cardiopulmonary bypass. Cardiovasc Surg 1999; 7:419-24.

26. Clavien PA, Durig M, Harder F. Venous mesenteric infarction: A particular entity. Br J Surg 1988;75:252-5.

27. Gore RM, Marn CS, Ujiki GT, et al. Ischemic colitis associated with systemic lupus erythematosus. Dis Colon Rectum 1983;26:449-51.

28. Wood MK, Read DR, Kraft AR, Barreta TM. A rare cause of ischemic colitis: Polyarteritis nodosa. Dis Colon Rectum 1979;22:428-33.

29. Koutroubakis IE, Sfiridaki A, Theodoropoulou A, Kouroumalis EA. Role of acquired and hereditary thrombotic risk factors in colon ischemia of ambulatory patients. Gastroenterology 2001;121:561-5.

30. Su C, Brandt LJ, Sigal SH, et al. The immunohistological diagnosis of E. coli O157:H7 colitis: Possible association with colonic ischemia. Am J Gastroenterol 1998;93:1055-9.

31. Cheung AN, Ng IO. Cytomegalovirus infection of the gastrointestinal tract in non-AIDS patients. Am J Gastroenterol 1993;88:1882-6.

32. Lucas W, Schroy PC III. Reversible ischemic colitis in a high endurance athlete. Am J Gastroenterol 1998;93:2231-4.

33. Deana DG, Dean PJ. Reversible ischemic colitis in young women. Association with oral contraceptive use. Am J Surg Pathol 1995; 19:454-62.

34. Carratu R, Parisi P, Agozzino A. Segmental ischemic colitis associated with nonsteroidal antiinflammatory drugs. J Clin Gastroenterol 1993;16:31-4.

35. Friedel D, Thomas R, Fisher RS. Ischemic colitis during treatment with alosetron. Gastroenterology 2001;120:557-60. 


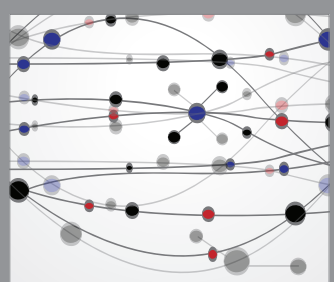

The Scientific World Journal
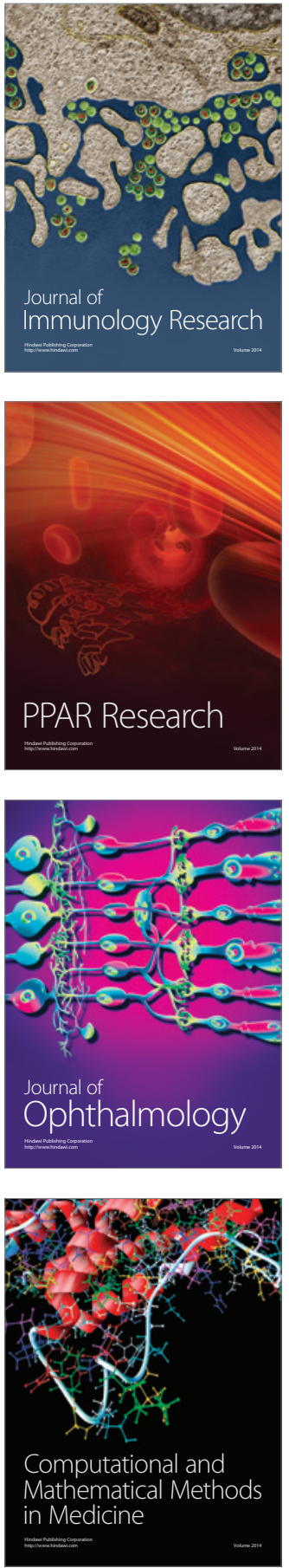

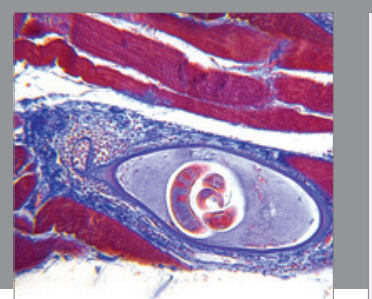

Gastroenterology Research and Practice

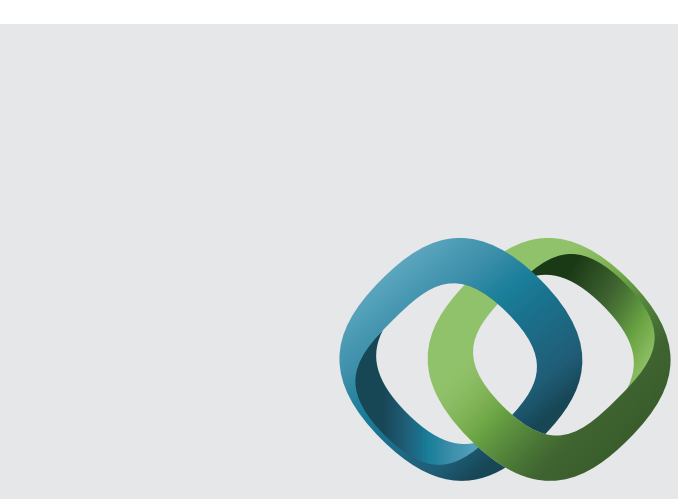

\section{Hindawi}

Submit your manuscripts at

http://www.hindawi.com
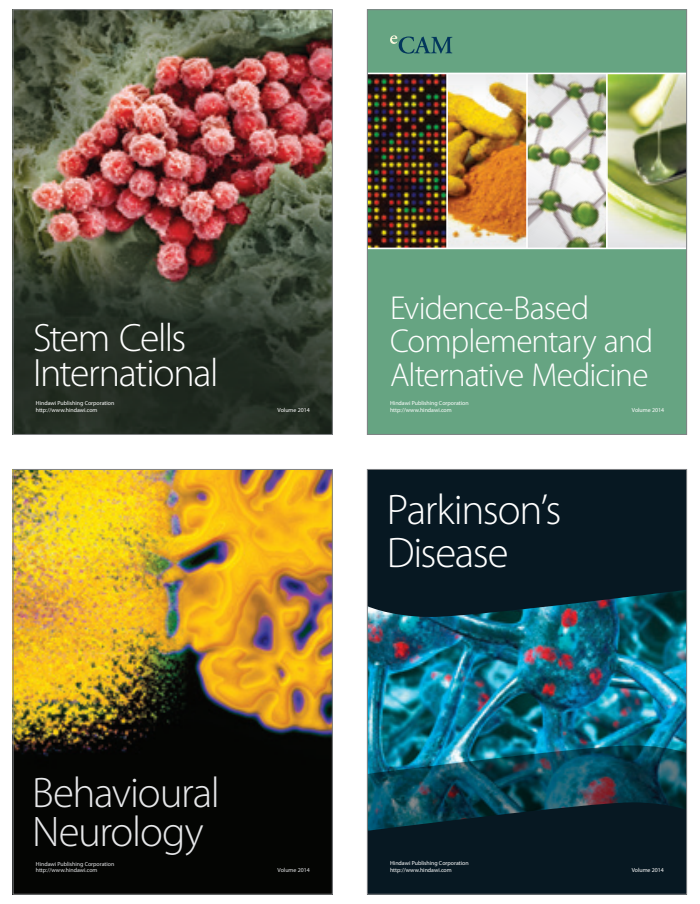
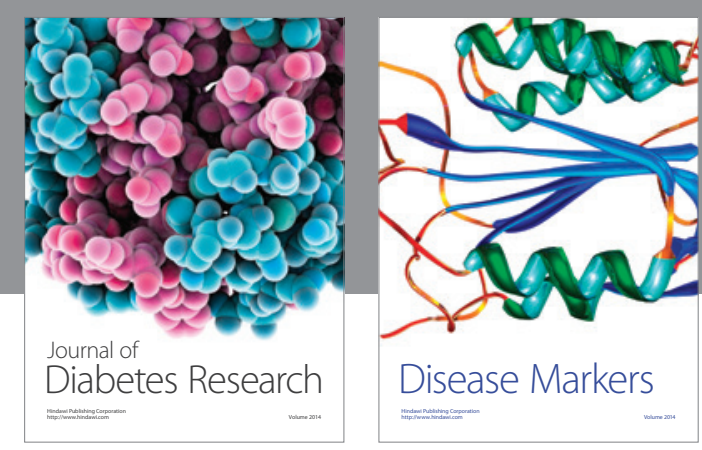

Disease Markers
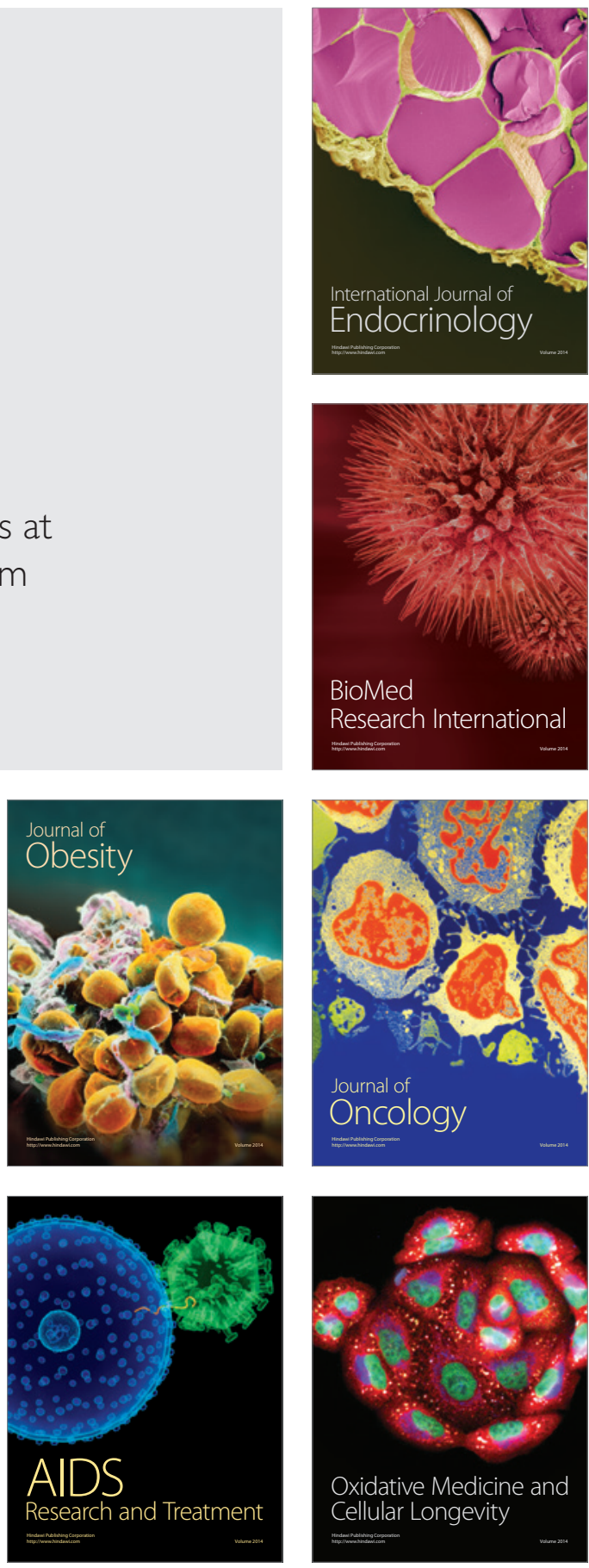